\title{
ANNOUNCEMENT OF PRIZE AWARD
}

$\mathrm{ON}_{\mathrm{N}}$ the completion of each volume of the fournal, the Committee of the Institute of Actuaries Students' Society may award a prize or prizes, not exceeding six guineas in total value, for meritorious contributions to the fournal.

In connexion with Vol. I4, the Committee has decided that a prize of six guineas should be awarded to C. J. CorNwall for his article: 'Friendly Society Amalgamations'.

The conditions of the award are as follows:

The award or awards shall be made after consideration of the contributions published in each volume of this fournal, whether by way of reprints of opening remarks made at sessional meetings or as original contributions to the fournal. Awards will be restricted to members of the Society who were not qualified at the date of the sessional meeting at which the remarks in question were made or at the date when the contribution first reached the hands of the Editors as the case may be, and to those who qualified during the three years preceding that date. The expression 'qualified' shall include Fellows of the Institute or the Faculty of Actuaries or those in possession of a qualification recognized by the Committee as being of equivalent standard. 